\title{
The Immobilization of Lipases on Porous Support by Adsorption and Hydrophobic Interaction Method
}

\author{
Nur Fathiah Mokhtar ${ }^{1}$, Raja Noor Zaliha Raja Abd. Rahman 1,2 ${ }^{10}$, Noor Dina Muhd Noor 1,3, \\ Fairolniza Mohd Shariff 1,2 and Mohd Shukuri Mohamad Ali 1,3,* \\ 1 Enzyme and Microbial Technology Research Center, Universiti Putra Malaysia, Serdang 43400, Malaysia; \\ nurfathiah93@gmail.com (N.F.M.); rnzaliha@upm.edu.my (R.N.Z.R.A.R.); dina@upm.edu.my (N.D.M.N.); \\ fairolniza@upm.edu.my (F.M.S.) \\ 2 Department of Microbiology, Faculty of Biotechnology and Biomolecular Science, Universiti Putra Malaysia, \\ Serdang 43400, Malaysia \\ 3 Department of Biochemistry, Faculty of Biotechnology and Biomolecular Science, Universiti Putra Malaysia, \\ Serdang 43400, Malaysia \\ * Correspondence: mshukuri@upm.edu.my; Tel.: +60-3-8947-1053
}

Received: 4 May 2020; Accepted: 6 June 2020; Published: 4 July 2020

\begin{abstract}
Four major enzymes commonly used in the market are lipases, proteases, amylases, and cellulases. For instance, in both academic and industrial levels, microbial lipases have been well studied for industrial and biotechnological applications compared to others. Immobilization is done to minimize the cost. The improvement of enzyme properties enables the reusability of enzymes and facilitates enzymes used in a continuous process. Immobilized enzymes are enzymes physically confined in a particularly defined region with retention to their catalytic activities. Immobilized enzymes can be used repeatedly compared to free enzymes, which are unable to catalyze reactions continuously in the system. Immobilization also provides a higher $\mathrm{pH}$ value and thermal stability for enzymes toward synthesis. The main parameter influencing the immobilization is the support used to immobilize the enzyme. The support should have a large surface area, high rigidity, suitable shape and particle size, reusability, and resistance to microbial attachment, which will enhance the stability of the enzyme. The diffusion of the substrate in the carrier is more favorable on hydrophobic supports instead of hydrophilic supports. The methods used for enzyme immobilization also play a crucial role in immobilization performance. The combination of immobilization methods will increase the binding force between enzymes and the support, thus reducing the leakage of the enzymes from the support. The adsorption of lipase on a hydrophobic support causes the interfacial activation of lipase during immobilization. The adsorption method also causes less or no change in enzyme conformation, especially on the active site of the enzyme. Thus, this method is the most used in the immobilization process for industrial applications.
\end{abstract}

Keywords: immobilization; enzyme; lipase; support; porous; adsorption; hydrophobic

\section{Introduction}

Enzymes are used in many large-scale industries, such as biofuel production, detergents, animal feed, food-based products (dairy, bakery, and fruit juices), and other applications such as paper, leather, and textiles processing [1,2]. In 2015, the US enzymes market value was estimated to be more than USD 1 billion, while the global value for enzymes was between $\$ 5000$ million and $\$ 5500$ million in 2016, which was led by three main enzymes known as carbohydrases, proteases, and lipases [3]. Lipases can be found widely in plants, animals, insects, and microorganisms such as bacteria and fungi. Lipases catalyze the hydrolysis of triglycerides, esterification, transesterification, and catalysis on 
unnatural substrates [4,5]. Lipases have broad substrate specificity and are suitable for applications in large-scale industries such as food, detergent, animal feed, pharmaceutical, and biodiesel production [6]. Besides substrate specificity, lipases have high yield production for industrial and biotechnological applications [4]. Lipase D (EC 3.1.1.3) is commercially used in the food processing industry, especially in the production of structured lipids as dietary ingredients derived from fats and oils [7,8]. For industrial use, an enzyme is immobilized on a support to increase its performance in terms of operational, storage, and thermal stability [8-10]. The immobilization of an enzyme requires three main parameters known as types of carriers or supports, techniques used for immobilization, and loading tests [2]. However, immobilized lipase can only be reused for several cycles of reactions with uncertain consistency affected by a simple adsorption technique and extreme chemical conditions during synthesis [11-13]. Therefore, the reusability of immobilized enzymes has been studied for the papain enzyme, which is reimmobilized back on the regenerated carrier recovered from the spent bound papain by using chelating metal ions to improve enzyme activity $[12,13]$.

Many studies about enzyme adsorption on a solid carrier were reviewed [14]. However, this review was focused only on the adsorption method to immobilize different types of enzymes such as laccase, lipase, $\alpha$-amylase, and trypsin. Nanomaterials (NMs) supports are also used to immobilize lipases, and the vital aspect of lipase immobilization was reviewed [15]. Based on the specific features of lipase and NMs, this review discussed the recent developments, some mechanisms, and the influence of NMs on lipase immobilization and their activity [10]. Besides, the enzyme immobilization method and enzyme carriers used for immobilization studies were reviewed [16-18]. Some advantages of immobilized lipase applications include reduced energy costs, shortened process times, the prevention of volatile compounds loss, and reduced risk of contamination $[19,20]$. All types of immobilization methods, such as adsorption, encapsulation, covalent bonding, entrapment, and crosslinking, were discussed in previous studies [16]. Carriers for enzyme immobilization are divided into inorganic materials, metal-organic frameworks (MOFs), DNA origami, and polymers [17]. Most of the review papers more focused on different types of enzymes used for various types of immobilization methods and supports $[19,20]$. The lipase immobilization on hydrophobic supports and the mechanism of lipase immobilization on hydrophobic supports using different types of immobilization techniques were reviewed [20]. However, among industrial applications, the adsorption method on porous supports is the most popular. Therefore, this review focuses only on lipase's immobilization using the adsorption and hydrophobic interaction method on a porous support.

\section{Advantages of Enzymes Immobilization}

Immobilization positively affects lipase stability at high temperatures [21,22]. Immobilized lipase exhibits higher activity compared with free lipase [23-26]. A study showed that the immobilized thermophilic Bacillus sp. lipase still retained $31.81 \%$ of the activity but deactivated free lipase activity [27]. The significant shift in the optimum reaction temperature occurs in free lipase from 37 to $50{ }^{\circ} \mathrm{C}$ for immobilized lipase [28]. The high temperature has less influence on the lipase activity, but it increases thermal stability [29]. The optimum temperature of immobilized lipase from Candida rugosa (ICRL) is from 20 to $50{ }^{\circ} \mathrm{C}$, while that of free Candida rugosa lipase is only from 40 to $50{ }^{\circ} \mathrm{C}$ [24]. The enzymatic activity of ICRL has a broader range of temperature, because yolk shells carriers help retain the lipase conformation in its active form [24,30]. The electrostatic charges changed after immobilization, which shifts the optimum $\mathrm{pH}$ of the immobilized enzyme to a slightly alkaline region [29]. The number of acidic groups increases after immobilization, which makes the enzyme gain more polyanionic character [13]. In alkaline environments, immobilized lipase has higher activity than free lipase $[24,30]$.

Moreover, immobilized lipase has better storage stability than free lipase based on previous studies [31,32]. In general, immobilized lipase displays full activity over a long period, indicating excellent stability of biocatalysts $[25,26]$. Immobilized enzymes are very stable, with a half-life of more than $1800 \mathrm{~h}$ under plant-operating conditions [33]. Immobilization enhances the enzyme properties by 
increasing the enzyme rigidity and heat tolerance, which is caused by low conformational flexibility of the enzyme and is generally indicated by an increase in the optimum temperature and stability against inactivation $[13,29]$. The improved thermal behavior of immobilized enzymes forms the basis of enzyme applications for many industrial processes requiring high temperatures [27,33].

In addition, the main factors important for industrial applications are the storage and operational stabilities of immobilized lipase [34]. A study showed the relative activity of ICRL maintained over $90.85 \%$ of the initial activity while that of free lipase was only $40 \%$ of the initial activity after 28 days of storage [24]. The storage stability of Candida rugose lipase was improved significantly, showing that the stable configuration of immobilized lipase was maintained after one month [24,34]. The Candida rugose lipase immobilization on yolk shells reduced its freedom to undergo changes in the stable conformation, which stabilized it against denaturing for an extended period compared to that of free lipase [35].

\section{Porous Carriers Used for the Immobilization of Lipase}

\subsection{Pore and Particle Sizes}

The presence of pores increases surface areas for enzyme adsorption [36-39]. Studies showed that the presence of micropores of silica aerogels protects lipase against alterations of the microenvironment and increases surface areas $[40,41]$. Porous carriers can be divided into three main categories, known as microporous, mesoporous, and macroporous materials [36,37]. Each type of support has different capabilities and disabilities [36]. The pore diameters on microporous supports are too small for enzyme diffusion, even though the supports have strong adsorption and large surface areas [37-39]. Mesoporous supports are commonly used to immobilize lipases and peroxidase [42,43]. Despite high surface areas and stability, the confinement of enzymes in mesopores with small pore size or non-open pore structures can decrease the enzymatic activity [44]. Mesoporous supports can cause major resistance during enzyme immobilization and diffusion [45,46]. Macroporous materials have a pore size at a micrometer scale that can significantly reduce the diffusional limitation [47]. The enzymes can be quickly immobilized on macroporous materials but also leach out quickly, mainly when the $\mathrm{pH}$ values of the media vary [48]. Macroporous supports only possess a small surface area and yield a low loading amount of enzymes, which is one of the significant problems in industrial applications [37,49].

The porosity of a support plays a significant role in the efficiency of immobilization [36,45]. The presence of pores increases the surface area of the support for lipase adsorption [46]. Pore exposure and particle size affect the binding of the substrate on the lipase [48]. Then, they affect the enzymatic reaction and the productivity of the reaction [50,51]. Polypropylene beads are well-known supports for the efficient immobilization of hydrolytic enzymes [52]. Generally, a macroporous polypropylene support (Accurel MP) consists of many pores on its surface [53-55]. A polypropylene support has a large surface area compared with other types of carriers, such as beads and nonporous supports [56]. Macroporous properties will increase the adsorption of lipase in the pores and surface of the support [52,57]. However, some lipases are desorbed from the support during the synthesis and continuous reaction [49]. A study was conducted to retrieve a support from immobilized papain but not an enzyme [12]. The scanning electron microscopy images showed the Ethylene glycol-bis [succinic acid N-hydroxysuccinimide] (EG-NHS) aggregates were smaller in size but had a larger surface area than bigger carrier free cross-linked enzyme aggregates using glutaraldehyde (GLA) [13]. Thus, more active sites at a large surface area are responsible for higher-mass transfer and activity enhancement [36,57].

\subsection{Criteria}

The criteria of the porous support use for lipase immobilization by adsorption and their applications are listed in Table 1. Due to high surface areas, porosity, pore size, and accessibility for binding, Rhizopus oryzae lipase immobilized in Lewatit ${ }^{\circledR}$ VP OC 1600 or Accurel ${ }^{\circledR}$ MP 1000 is presented to 
have the best performance regarding oleic acid incorporation (mol.\%) on tripalmitin [8]. Macroporous Sepabeads have a small pore size (100-200 $\AA$ ), which adsorbs 10-fold more active Thermomyces lanuginosus lipase than mesoporous Purolite C-18 (pore size: $616 \AA$ ), and are able to be transported with highly viscous reaction media [58]. Thus, the pore size of supports plays a vital role in the modification of oils in solvent-free systems. The treatment of supports with solvents maximizes the adsorption rate and the immobilization yield for lipase B from Candida antarctica (CALB) onto Accurel MP1001 (particle size $<1000 \mu \mathrm{m}$ ) and styrene-divinylbenzene porous supports $(75-150 \mu \mathrm{m})[59,60]$.

However, some textural changes on mesoporous carbon beads have less impact on the protein adsorption and catalytic activity of lipases from Candida antarctica [71] similar to on immobilized lipase that exhibits a decrease in the specific surface area and pore volume due to the loss of the adsorbed lipase and the comb polymer [73]. The physicochemical properties of macroporous resin NKA matrix supports are crucial for Burkholderia cepacia lipase immobilization, which influences enzyme loading as well as catalytic behavior [69]. A study showed that macroporous supports $(5-50 \mu \mathrm{m})$ provide channels for mass transfer of Phospholipase D and substrates while mesoporous supports $(10-50 \mathrm{~nm})$ have high surface areas for enzyme adsorption [37]. Besides, polystyrenic macroporous resin (Purolite ${ }^{\circledR}$ A109), which has better internal diffusional properties, excellent mechanical stability, high particle diameters $(400 \mu \mathrm{m})$, and robustness, enables the efficient application of immobilized Candida sp. in bioreactors [31]. The optimal mass diffusion of the substrate is achieved by the three-dimensional mesoporous network of ordered mesoporous materials (OMMs), which is useful to immobilize lipase via hydrophobic interaction [74]. Poly(MMA-co-DVB) hydrophobic porous, polymer-encapsulated magnetic microspheres provide an effective system for Mucor javanicus lipase immobilization that has a 200-fold specific activity increase and reusable cycles of more than 30 times in high-viscosity reaction systems for the solvent-free synthesis of 1,3-diolein [70].

Furthermore, the design of a mesoporous SBA-15 support is tailored to improve enzyme immobilization and have benefits such as hydrophobic character, high surface areas, large pore volumes, and parallel channels [72]. The lamellar structures of mesoporous cuttlebone powder of Sepia officinalis (CBP) also have a large surface area, which is most suitable to entrap more biomolecules on its surface during immobilization [63]. Moreover, the particle size also affects the enzyme immobilization and reaction rates, both of which are influenced by the amount of interfacial area per unit volume [64]. The modified hollow mesoporous silica support (HMSS) exhibits monodisperse, uniform, and spherical morphology with a particle size of $3.8 \mu \mathrm{m}$. The hydrophobic microenvironment, an appropriate pore size of the HMSS, and a large cavity volume cause a higher catalytic reaction for immobilized Candida rugosa lipase (HMSS-C18-CRL) [75]. The smaller particle size of the support has a larger surface area [66], in which a smaller particle EP400 support has a more abundant surface area for enzyme adsorption and provides substrate access during the hydrolysis reaction better than a larger particle support [64]. A particle size of $300 \mathrm{~nm}$ was proven to be the most suitable carrier for both lipases from Mucor miehei and Rhizopus oryzae [66].

In addition, the uniform distribution of CALB on smaller particles of resin increases due to a large surface area [61], and enzymes are adsorbed rapidly for a particle size of $120 \mu \mathrm{m}$ [62]. The optimized pore size and a highly hydrophobic surface of a mesoporous silica nanoparticles (MSNs) support increased lipase adsorption and beneficial for obtaining high loading and better stability [67]. The desorption of Thermomyces lanuginosus lipase from a mesoporous support is reduced due to the strong hydrophobic interaction of lipase with the internal support surface [68]. However, a study shows that ethanol pretreatment of porous supports provide the interfacial activation of lipase to be adsorbed on the hydrophobic surface [65]. 
Table 1. Criteria of porous support use for lipase immobilization by adsorption.

\begin{tabular}{|c|c|c|c|c|c|}
\hline Lipase Source & Support & Surface Area & Particle Size & Pore Size & Reference \\
\hline $\begin{array}{l}\text { Phospholipase D } \\
\text { from Streptomyces sp. }\end{array}$ & $\begin{array}{l}\text { Novel epoxy resin-based } \\
\text { hierarchical porous } \\
\text { polymers (HPSs) }\end{array}$ & $225-156 \mathrm{~m}^{2} / \mathrm{g}$ & $\begin{array}{l}\text { Ultramacropore } \\
(5-50 \mu \mathrm{m}) ; \\
\text { Macropore } \\
(0.1-5 \mu \mathrm{m}) ; \\
\text { Mesopore } \\
(10-50 \mu \mathrm{m})\end{array}$ & - & [37] \\
\hline $\begin{array}{l}\text { Lipase B from } \\
\text { Candida antarctica } \\
\text { (CALB) }\end{array}$ & Methyl methacrylate resins & $500 \mathrm{~m}^{2} / \mathrm{g}$ & $560-710 \mu \mathrm{m}$ & $250 \AA$ & {$[61]$} \\
\hline CALB & Polystyrene resins & - & $350-600 \mu \mathrm{m}$ & $300-1000 \AA$ & [62] \\
\hline $\begin{array}{l}\text { AKL } 13 \text { lipase from } \\
\text { Bacillus subtilis (BsL) }\end{array}$ & $\begin{array}{l}\text { Mesoporous cuttlebone powder } \\
\text { of Sepia officinalis (CBP) }\end{array}$ & $1.631 \mathrm{~m}^{2} / \mathrm{g}$ & $89.95 \mu \mathrm{m}$ & - & [63] \\
\hline \multirow{2}{*}{$\begin{array}{l}\text { Candida rugosa } \\
\text { (OF360) }\end{array}$} & \multirow[b]{2}{*}{ Polyolefin (Accurel) } & EP100: $50-90 \mathrm{~m}^{2} / \mathrm{g}$ & $<200 \mu \mathrm{m}$ & $0.1-1.0 \mu \mathrm{m}$ & \multirow{2}{*}[64]{} \\
\hline & & EP400: $20-40 \mathrm{~m}^{2} / \mathrm{g}$ & $<400 \mu \mathrm{m}$ & $0.1-0.5 \mu \mathrm{m}$ & \\
\hline $\begin{array}{l}\text { Thermomyces } \\
\text { lanuginosus } \\
\text { lipase (TLL) }\end{array}$ & $\begin{array}{l}\text { Poly-methacrylate } \\
\text { particles (PMA) }\end{array}$ & $500 \mathrm{~m}^{2} / \mathrm{g}$ & $300-700 \mu \mathrm{m}$ & $170 \AA$ & [65] \\
\hline \multirow{3}{*}{$\begin{array}{l}\text { Mucor miehei and } \\
\text { Rhizopus oryzae }\end{array}$} & \multirow{3}{*}{ Mesoporous silica (MPS) } & $\begin{array}{l}\text { MPS-1000: } \\
502 \mathrm{~m}^{2} / \mathrm{g}\end{array}$ & $1000 \mathrm{~nm}$ & $9.3 \mathrm{~nm}$ & \multirow{3}{*}[66]{} \\
\hline & & MPS-300: $606 \mathrm{~m}^{2} / \mathrm{g}$ & $300 \mathrm{~nm}$ & $9.4 \mathrm{~nm}$ & \\
\hline & & MPS-40: $463 \mathrm{~m}^{2} / \mathrm{g}$ & $40 \mathrm{~nm}$ & $9.1 \mathrm{~nm}$ & \\
\hline Candida rugosa & $\begin{array}{l}\text { Octadecylalkyl-modified } \\
\text { mesoporous silica nanoparticles } \\
\text { (C18-MSNs) }\end{array}$ & $219-486 \mathrm{~m}^{2} / \mathrm{g}$ & $37-45 \mathrm{~nm}$ & $1.6-5.4 \mathrm{~nm}$ & [67] \\
\hline $\begin{array}{l}\text { Thermomyces } \\
\text { lanuginosus }\end{array}$ & $\begin{array}{l}\text {-Mesoporous hydrophobic } \\
\text { poly-methacrylate particles } \\
\text { (Diaion }{ }^{\circledR} \text { HP 2-MG) } \\
\text {-Mesoporous PMA particles } \\
\text { (Diaion }{ }^{\circledR} \text { HP 2-MG) }\end{array}$ & $500 \mathrm{~m}^{2} / \mathrm{g}$ & $300-700 \mu \mathrm{m}$ & $170 \AA$ & [68] \\
\hline Burkholderia cepacia & $\begin{array}{l}\text { Macroporous resin NKA } \\
\text { (polystyrene) }\end{array}$ & $570 \mathrm{~m}^{2} / \mathrm{g}$ & $300 \mu \mathrm{m}$ & $200 \AA$ & [69] \\
\hline $\begin{array}{l}\text { Mucor javanicus } \\
\text { lipase }\end{array}$ & $\begin{array}{l}\text { Poly(methylmethacrylate-co } \\
\text { divinylbenzene)-encapsulated } \\
\text { porous magnetic microspheres }\end{array}$ & $12 \mathrm{~m}^{2} / \mathrm{g}$ & - & $170 \mathrm{~nm}$ & {$[70]$} \\
\hline Candida sp. L3170 & $\begin{array}{l}\text { Purolite }{ }^{\circledR} \text { A } 109 \text {, polystyrenic } \\
\text { macroporous } \\
\text { resin }\end{array}$ & - & $400 \mu \mathrm{m}$ & - & [31] \\
\hline CALB & $\begin{array}{l}\text { Styrene-divinylbenzene MCI } \\
\text { GEL CHP20P porous support }\end{array}$ & $>500 \mathrm{~m}^{2} / \mathrm{g}$ & $75-150 \mu \mathrm{m}$ & $400-600 \AA$ & {$[60]$} \\
\hline $\begin{array}{l}\text { Lipases A and B from } \\
\text { Candida antarctica }\end{array}$ & Mesoporous carbon beads & $>800 \mathrm{~m}^{2} / \mathrm{g}$ & $0.5-1 \mathrm{~mm}$ & - & [71] \\
\hline CALB & $\begin{array}{l}\text { Pore-expanded mesoporous } \\
\text { silica (SBA-15) }\end{array}$ & $526 \mathrm{~m}^{2} / \mathrm{g}$ & - & $14 \mathrm{~nm}$ & {$[72]$} \\
\hline \multirow[t]{2}{*}{ CALB } & \multirow{2}{*}{$\begin{array}{l}\text { Accurel MP (a macroporous } \\
\text { propylene) }\end{array}$} & \multirow{2}{*}{$78.92 \mathrm{~cm}^{2} / \mathrm{g}$} & $\begin{array}{c}\text { MP1000: }<1500 \\
\mu \mathrm{m}\end{array}$ & $10 \mathrm{~nm}$ & \multirow{2}{*}{ [59] } \\
\hline & & & $\begin{array}{c}\text { MP1001: }<1000 \\
\mu \mathrm{m}\end{array}$ & $8 \mu \mathrm{m}$ & \\
\hline \multirow{2}{*}{$\begin{array}{l}\text { Thermomyces } \\
\text { lanuginosus }\end{array}$} & \multirow{2}{*}{$\begin{array}{l}\text { Macroporous Purolite C-18 } \\
\text { mesoporous Sepabeads C-18 }\end{array}$} & $116 \mathrm{~m}^{2} / \mathrm{g}$ & - & $616 \AA$ & \multirow{2}{*}{ [58] } \\
\hline & & $60-80 \mathrm{~m}^{2} / \mathrm{g}$ & & $100-200 \AA$ & \\
\hline \multirow[t]{2}{*}{$\begin{array}{l}\text { Heterologous } \\
\text { Rhizopus oryzae }\end{array}$} & \multirow{2}{*}{$\begin{array}{l}\text { Accurel MP } 1000 \\
\text { (polypropylene) Lewatit }{ }^{\circledR} \text { VP } \\
\text { OC } 1600\end{array}$} & $70 \mathrm{~m}^{2} / \mathrm{g}$ & $50-1000 \mu \mathrm{m}$ & $2000 \AA$ & \multirow[t]{2}{*}{ [8] } \\
\hline & & $130 \mathrm{~m}^{2} / \mathrm{g}$ & $315-100 \mu \mathrm{m}$ & $15 \AA$ & \\
\hline $\begin{array}{l}\text { Burkholderia ambifaria } \\
\text { (YCJ01) }\end{array}$ & $\begin{array}{l}\text { Mesoporous } \mathrm{TiO} 2 \text { modified with } \\
\text { an comb polymer-poly(sodium } \\
\text { acrylate)-g-methoxy } \\
\text { poly(ethylene oxide) }\end{array}$ & $38.02 \mathrm{~m}^{2} / \mathrm{g}$ & - & $16.25 \mathrm{~nm}$ & [73] \\
\hline Burkholderia cepacia & $\begin{array}{l}\text { Phenyl-modified ordered } \\
\text { mesoporous silica }\end{array}$ & $152 \mathrm{~m}^{2} / \mathrm{g}$ & $8-10 \mu \mathrm{m}$ & $21.3 \mathrm{~nm}$ & [74] \\
\hline Candida rugosa & $\begin{array}{l}\text { Modified hollow mesoporous } \\
\text { silica (HMSS) }\end{array}$ & $399 \mathrm{~m}^{2} / \mathrm{g}$ & - & $12 \mathrm{~nm}$ & [75] \\
\hline
\end{tabular}




\section{Types of Immobilization Methods on the Support/Carrier-Binding Method}

Lipases can be immobilized using different methods such as covalent attachment, adsorption, encapsulation, entrapment, and crosslinking on numerous supports (Figure 1). The carrier-binding method is the most commonly used in large-scale immobilization processes $[76,77]$. The carrier-binding method is conducted based on a weak binding force, such as physical adsorption, ionic bonding, and covalent bonding of enzymes on the surface of water-insoluble supports [78]. Thus, this method causes less or no change in enzyme conformation, especially on the active site of an enzyme [6,14]. The physical adsorption method with a proper support, such as synthetic polymers, exhibits excellent mechanical rigidity, high specific areas, and reusable capability for several cycles of reactions [2]. The second method, known as entrapment, is much more stable than physically adsorbed lipase [79]. Next is the crosslinking technique by reagent glutaraldehyde, which forms chemical bonds like covalent bonding without the use of a water-insoluble carrier [13,29]. Glutaraldehyde is the most common reagent used for crosslinking of lipase on porus polypropylene carriers, and the yield achieves $98 \%$, which is higher than that of free lipase [79]. Various immobilization methods are shown in Figure 1.

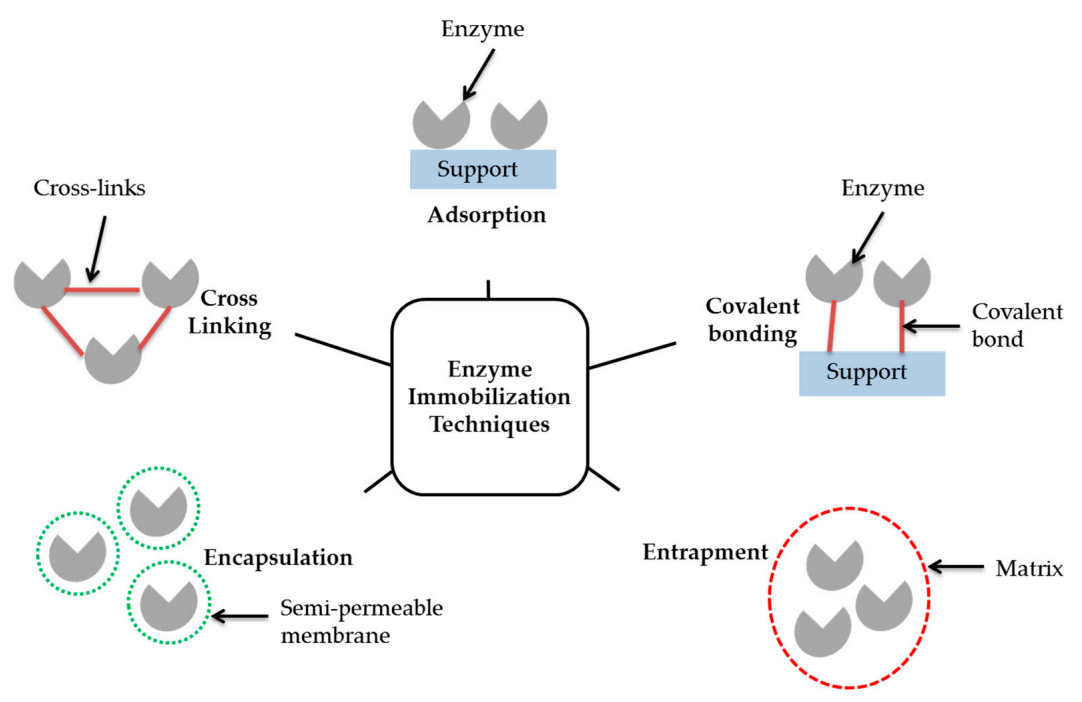

Figure 1. Scheme of various enzyme immobilization techniques.

The selection of suitable immobilization techniques is essential to ensure the practical usage of enzymes without leakage or detachment from supports $[79,80]$. Initially, porous glass beads, diatomaceous earth, silica, and alumina are standard supports used for lipase immobilization, but many new supports were used in recent studies [80,81]. The combination of a proper support and immobilization methods will increase the binding force between the enzymes and the support, thus reducing the leakage of the enzymes from the support (Table 2).

Table 2. Immobilization methods and supports materials.

\begin{tabular}{ccc}
\hline Physical Method & Chemical Method & Support Material \\
\hline Adsorption & Covalent attachment & Magnetic nanoparticles \\
\hline $\begin{array}{c}\text { Entrapment (gel/fiber entrapping, } \\
\text { microencapsulation, and metal-organic } \\
\text { frameworks (MOFS) embedding) }\end{array}$ & Crosslinking (crosslinking to a support & Membranes \\
& matrix, CLEAs) & Ionic bonding \\
& Conjugation by affinity ligands & Capillary columns \\
\end{tabular}

\section{Effect of a Solvent on a Porous Support}

It has been reported that the amount of adsorbed lipase on a pretreated support by ethanol is 2 -fold higher than an untreated support $[56,82]$. With pretreatment by ethanol, the porous carrier 
increases hydrophobicity and immobilization rates [82]. Besides, the pretreated immobilized enzyme has better stability in broad temperature and $\mathrm{pH}$ ranges [32,82]. A similar pattern is exhibited by a native lipase, which has an optimum temperature at $37^{\circ} \mathrm{C}$ but increases to $50{ }^{\circ} \mathrm{C}$ after immobilization on hydrophobic microspheres [5]. Several publications agree on the enhancement of the support affinity to lipase aqueous solutions due to the ethanol pretreatment of the support [82]. The ethanol pretreatment of the support leads to a more uniform catalyst with a higher adsorption efficiency and increases solid recovery [83]. The initial size of supports becomes smaller due to the stirring during the immobilization process $[66,83]$. The size of the immobilized Candida antarctica on a polypropylene support (CA/PP) at the beginning and the final stage of the immobilization procedure deserves great attention. An additional size reduction of CA/PP particles during the reaction complicates their recovery and prevents their reuse $[82,83]$.

Pretreatment of Accurel MP is needed to improve the penetration of an aqueous lipase solution into hydrophobic Accurel MP pores [84,85]. In the literature, two protocols are described: protocol A consists in wetting a support in a sequence of ethanol, an aqueous ethanol solution, and finally with water, with intermediary filtration [86,87]; protocol B consists in a single wetting with ethanol and then directly contact with an enzyme solution without removing ethanol [86]. With CALB being well-known for its strong tolerance to high solvent quantities, a third method (protocol C) was proposed by replacing ethanol in protocol B with a more polar solvent, acetone [88]. It was checked that no loss of enzyme activity occurred when acetone or ethanol was added to the lipase solution under the same conditions during the immobilization process over $48 \mathrm{~h}$ at room temperature [48]. Ethanol improves the immobilization process by inducing better penetration of the enzyme solution inside the highly hydrophobic Accurel MP and by reducing the enzyme thermodynamic activity, thus forcing the adsorption process $[77,89]$.

\section{Interfacial Activation of Lipase on a Hydrophobic Porous Support}

The success of lipase adsorption on a hydrophobic support depends on the structural domain called lid $[57,90]$. The lid contributes to providing an open and closed configuration to the enzyme $[83,91]$. In the closed conformation, hydrophobic residues face toward the catalytic site (inside the lid), thus preventing substrate binding [91]. The open conformation of lid occurs in the presence of a hydrophobic interface. The catalytic site is exposed outside the lid and bound to the substrate, which causes the phenomenon known as "interfacial activation" [91,92].

The interfacial activation of lipase occurs, when the enzyme is adsorbed on the hydrophobic surface and causes open conformation lipase $[65,93]$. The reversible mechanism of immobilization permits reusing supports after enzyme inactivation [92,93]. However, it should be considered, as already described in other publications, that this reduces the range of applicable cosolvent concentrations and even some substrates or products may produce the release of the enzyme [92]. Simple strategies to solve this problem have been proposed, enlarging the application range of this immobilized enzyme $[82,88,93]$. The interfacial activation of lipase on a hydrophobic support is shown in Figure 2.

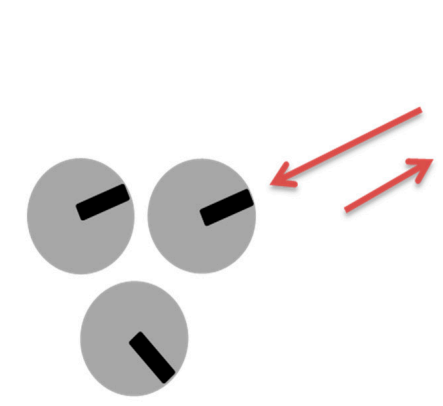

Closed form

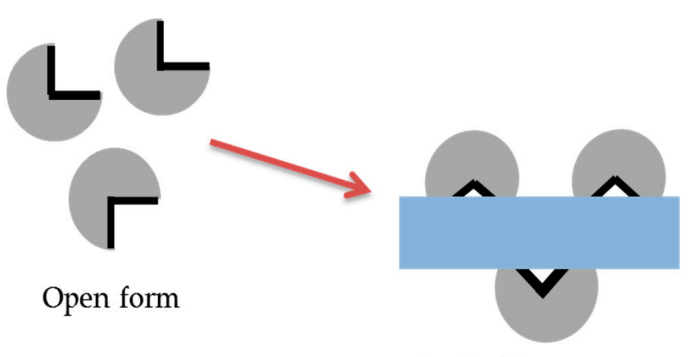

Adsorbed lipase via interfacial activation on hydrophobic support

Figure 2. Scheme of immobilization by interfacial activation on a hydrophobic support. 


\section{Application of Lipases Immobilized on a Porous Support}

Many studies have been conducted on the immobilization of lipases on hydrophobic porous supports $[56,60,63,76]$. Higher temperatures will break bond interactions within a protein structure that is responsible for a proper globular catalytic active structure [90-93]. However, thermal effects become less prominent toward the immobilized lipase $[90,91]$. Since a porous support has a large surface area for lipase adsorption, hierarchical porous polymers (HPSs) are used to immobilize phospholipase D and catalyze transphosphatidylation [37]. The optimum temperature for immobilizing phospholipase $\mathrm{D}$ is increased by $5{ }^{\circ} \mathrm{C}$ compared to that for free lipase. After 28 days, the immobilized phospholipase $\mathrm{D}$ still had $80 \%$ of activity, which is higher than free lipase [37]. The hydrolysis of triglyceride esters (high oleate sunflower oil) is catalyzed by Candida rugosa lipase on a macroporous polyolefin support [64]. The immobilized Candida rugosa lipase reaches half-life at a longer time compared to free lipase [24,25]. Some advantages of immobilized lipase applications include reduced energy costs, shortened process times, prevention of loss of volatile compounds, and reduced risk of contamination [94,95]. Besides, the reusability of lipases also increases after immobilization. A study showed the immobilized lipase B from Candida rugosa was reused for six cycles of reaction to catalyze the esterification of free fatty acids obtained from soybean-oil hydrolysis and different polyols [96]. The same lipase from Candida rugosa was immobilized and showed better storage stability than free lipase after four weeks of incubation [64].

The immobilized lipase from Staphylococcus warneri (EX17) and Burkholderia ambifaria (YCJ01) is used to catalyze the synthesis of short-chain esters, which has a fruity flavor similar to the pineapple, which can be used in flavors, fragrances, fine chemicals, and food industry [97,98]. Soybean oil is used as substrates for the synthesis of fatty acid methyl esters by CALB and the glycerolysis of soybean oil by lecitase ultra (phospholipase) [99]. Immobilized lipase is vital for large-scale industrial production. The leading enzyme producers, such as Amano, Novozymes, DSM, and AB ENZYMES, have to supply various enzymes for industrial purposes [100]. Currently, practical systems that have already been adopted in industrial production are the industry sectors, such as fats and oleo-chemistry, detergent, polymers, biodiesel, and food processing [101]. These industry sectors utilize immobilized lipase to achieve the optimum condition for the large-scale industry production. For instance, the fats and oleo chemistry industry uses immobilized lipase to catalyze the hydrolysis, esterification, and inter-esterification of oils and fats as an alternative to physicochemical processes (energy-saving and the specificity of reactions) $[100,101]$. The applications of immobilized lipase on porous supports under optimum conditions are listed in Table 3. 
Table 3. Lipase immobilization on porous supports under optimum conditions for various applications.

\begin{tabular}{|c|c|c|c|c|c|c|}
\hline Source & Temperature $\left({ }^{\circ} \mathrm{C}\right)$ & $\mathrm{pH}$ & Reusability & Stability & Application & Reference \\
\hline $\begin{array}{l}\text { Heterologous } \\
\text { Rhizopus oryzae }\end{array}$ & 60 & 7 & 2 batches & - & $\begin{array}{l}\text { Synthesis of human milk fat } \\
\text { substitutes }\end{array}$ & [8] \\
\hline Candida sp. (L3170) & 25 & 7 & - & $\begin{array}{c}\text { Free lipase: } 1-1.4 \mathrm{~h} ; \\
\text { Immobilized lipase: } 2.4 \mathrm{~h}\end{array}$ & $\begin{array}{l}\text { Hydrolysis of p-nitrophenyl } \\
\text { butyrate }\end{array}$ & [31] \\
\hline Rhizopus oryzae & 37 & wide & 12 & 4 months & $\begin{array}{l}\text { n-butyl oleate synthesis by } \\
\text { esterification of oleic acid with } \\
\text { n-butanol }\end{array}$ & [32] \\
\hline $\begin{array}{l}\text { Phospholipase D } \\
\text { (Streptomyces sp.) }\end{array}$ & $\begin{array}{l}\text { Free lipase: } 40 \\
\text { Immobilized lipase: } \\
45\end{array}$ & $\begin{array}{c}\text { Free lipase: } 6 \\
\text { Immobilized lipase: } \\
6.5\end{array}$ & 12 & $\begin{array}{c}\text { After } 28 \text { days, } \\
\text { Free lipase: } 25 \% \text {; } \\
\text { Immobilized lipase: } 80 \%\end{array}$ & $\begin{array}{l}\text { Catalysis of the } \\
\text { transphosphatidylation from } \\
\text { phosphatidylcholine PC to } \\
\text { phosphatidylserine PS }\end{array}$ & [37] \\
\hline $\begin{array}{l}\text { Thermomyces } \\
\text { lanuginosus }\end{array}$ & 40 & 7 & - & 20 days & $\begin{array}{l}\text { Hydrolysis of } 0.4 \mathrm{mM} \\
\text { p-nitrophenyl butyrate (pNPB) } \\
\text {-ethanolysis of sunflower oil }\end{array}$ & [58] \\
\hline CALB & 60 & 7.2 & - & - & Continuous oil transesterification & [59] \\
\hline CALB & $20-25$ & 7.8 & - & - & Polyester synthesis & [61] \\
\hline $\begin{array}{l}\text { Bacillus subtilis AKL } \\
13 \text { lipase (BsL) }\end{array}$ & 50 & - & 15 & - & $\begin{array}{l}\text { p-nitrophenol palmitate } \\
\text { hydrolysis }\end{array}$ & [63] \\
\hline $\begin{array}{l}\text { Fungal yeast Candida } \\
\text { rugosa OF360 }\end{array}$ & $\begin{array}{l}30 \\
45\end{array}$ & $7-9$ & - & $\begin{array}{c}\text { Free enzyme: } 310.03 \mathrm{~h} \text {; } \\
\text { EP400: } 2100.71 \text { h; EG100: } \\
1008.16 \mathrm{~h}\end{array}$ & $\begin{array}{l}\text { Catalytic hydrolysis of } \\
\text { triglyceride esters } \\
\text {-hydrolysis of high oleate } \\
\text { sunflower oil }\end{array}$ & [64] \\
\hline TLL & 45 & 8 & 12 & - & $\begin{array}{l}\mathrm{n} \text {-Octyl oleate was synthesized } \\
\text { by enzymatic esterification } \\
\text { reaction of oleic acid and } \\
\mathrm{n} \text {-octanol } \\
\text {-used as a lubricant in industrial } \\
\text { processes }\end{array}$ & [65] \\
\hline Candida rugosa & 40 & 7.4 & 5 & - & $\begin{array}{l}\text { Hydrolysis of 4-nitrophenyl } \\
\text { palmitate }\end{array}$ & [67] \\
\hline $\begin{array}{l}\text { Thermomyces } \\
\text { lanuginosus }\end{array}$ & $55-60$ & 9 & 22 & - & $\begin{array}{l}\text { Hydrolysis of olive oil emulsion } \\
\text {-synthesis of isoamyl oleate } \\
\text { (biolubricant) by esterification } \\
\text { reaction. }\end{array}$ & [68] \\
\hline Burkholderia cepacia & 37 & 7 & 50 & - & Synthesis of methyl esters & [69] \\
\hline
\end{tabular}


Table 3. Cont.

\begin{tabular}{|c|c|c|c|c|c|c|}
\hline Source & Temperature $\left({ }^{\circ} \mathrm{C}\right)$ & $\mathrm{pH}$ & Reusability & Stability & Application & Reference \\
\hline Mucor javanicus & & 8 & $\begin{array}{l}\text { Free lipase: } 5 \text {; } \\
\text { Immobilized } \\
\text { lipase: } 30\end{array}$ & - & $\begin{array}{l}\text { Esterification of glycerol and } \\
\text { oleic acid }\end{array}$ & [70] \\
\hline $\begin{array}{l}\text { Lipases A and B from } \\
\text { Candida antarctica }\end{array}$ & 29.85 & $\begin{array}{c}\text { Free lipase: } 7 \\
\text { CALA/MB: } 5 \\
\text { CALA/MB: 1500-4 } \\
\text { CALA/MB: LTA-5 } \\
\text { CALB/MB: } 5 \\
\text { CALB/MB: 1500-6 } \\
\text { CALB/MB-LTA: } 5 \text { and } \\
7\end{array}$ & 10 & - & $\begin{array}{l}\text { Kinetic resolution of } \\
( \pm)-1 \text {-phenylethanol }\end{array}$ & [71] \\
\hline Recombinant CALB & 25 & 5 & 5 & - & $\begin{array}{l}\text { Production of methyl and ethyl } \\
\text { butyrate, hydrolysis of ethyl } \\
\text { hexanoate }\end{array}$ & [72] \\
\hline $\begin{array}{l}\text { Burkholderia ambifaria } \\
\text { (YCJ01) }\end{array}$ & 40 & 7.5 & 6 & - & $\begin{array}{l}\text { Resolution of } \\
\text { 3-phenoxy-1,2-propanediol }\end{array}$ & [73] \\
\hline Burkholderia cepacia & 35 & 7 & 50 cycles & - & Resolution of 1-phenylethanol & [74] \\
\hline $\begin{array}{c}\text { Candida rugosa lipase } \\
\text { (CRL) }\end{array}$ & 37 & 7 & 21 & $\begin{array}{c}\text { After } 120 \mathrm{~min}, \\
\text { Free lipase: } 30 \% ; \\
\text { Immobilized lipase: } 90 \%\end{array}$ & $\begin{array}{l}\text { Esterification of phytosterols } \\
\text { with polyunsaturated fatty acid } \\
\text { (PUFA) }\end{array}$ & [75] \\
\hline Burkholderia cepacia & 25 & 6.5 & $>5$ & - & $\begin{array}{l}\text { Transesterification resolution of } \\
\text { racemic aromatic secondary } \\
\text { alcohols to synthesize chiral } \\
\text { intermediates }\end{array}$ & [90] \\
\hline $\begin{array}{l}\text { Lipomod 34MDP } \\
\text { (free lipase from } \\
\text { Candida rugosa) }\end{array}$ & 40 & 7 & 6 & - & $\begin{array}{l}\text { Esterification of free fatty acids } \\
\text { obtained from soybean-oil } \\
\text { hydrolysis and different polyols } \\
\text { (neopentyl glycol, NPG; } \\
\text { trimethylolpropane, TMP; and } \\
\text { pentaerythritol }\end{array}$ & [96] \\
\hline $\begin{array}{l}\text { Staphylococcus warneri } \\
\text { lipase (EX17) }\end{array}$ & $30-45$ & 7 & - & - & $\begin{array}{l}\text { Catalysis of the synthesis of ethyl } \\
\text { butyrate } \\
\text { a short-chain ester, which has a } \\
\text { fruity flavor similar to the } \\
\text { pineapple and can find } \\
\text { applications in the food industry. }\end{array}$ & [97] \\
\hline
\end{tabular}


Table 3. Cont.

\begin{tabular}{|c|c|c|c|c|c|c|}
\hline Source & Temperature $\left({ }^{\circ} \mathrm{C}\right)$ & $\mathrm{pH}$ & Reusability & Stability & Application & Reference \\
\hline $\begin{array}{l}\text { Burkholderia ambifaria } \\
\text { lipase (YCJ01) }\end{array}$ & 50 & $\begin{array}{c}\text { Free lipase: } 7.5 \\
\text { Immobilized lipase: } 7\end{array}$ & 10 & - & $\begin{array}{l}\text { Cinnamyl acetate synthesis } \\
\text {-an essential ingredient, which is } \\
\text { widely used in the synthesis of } \\
\text { flavors, fragrances, and fine } \\
\text { chemicals }\end{array}$ & [98] \\
\hline $\begin{array}{l}\text { Lecitase ultra } \\
\text { (phospholipase) }\end{array}$ & 45 & 7 & 28 & - & $\begin{array}{l}\text { Glycerolysis of soybean oil } \\
\text {-catalyzing glycerolysis } \\
\text { of soybean oil to produce DAG }\end{array}$ & [99] \\
\hline Candida sp. & 40 & 7.4 & 19 & - & Production of biodiesel & [102] \\
\hline Yarrowia lipolytica & 40 & 8 & 5 & - & $\begin{array}{l}\text { Enrichment of polyunsaturated } \\
\text { fatty acids }\end{array}$ & [103] \\
\hline CALB & 30 & 7.4 & 10 & 35 days $(94.41 \%)$ & $\begin{array}{l}\text { Methyl esterification of oleic acid } \\
\text { Hydrolysis of rac-methyl }\end{array}$ & [104] \\
\hline $\begin{array}{l}\text { CALB, Rhizomucor } \\
\text { miehei lipase }\end{array}$ & 25 & 7 & - & - & $\begin{array}{l}\text { mandelate } \\
\text { Regioselective hydrolysis of } \\
\text { triacetin }\end{array}$ & [105] \\
\hline $\begin{array}{l}\text { Thermomyces } \\
\text { lanuginosus }\end{array}$ & 50 & 7 & - & - & Synthesis of butyl butyrate & [106] \\
\hline Aspergillus niger & 50 & & 8 cycles $(<50 \%)$ & - & Preparation of biodiesel & [107] \\
\hline
\end{tabular}




\section{Conclusions and Expectation}

Lipase is the most versatile enzyme, which can be absorbed on hydrophobic supports, which experience the interfacial activation during the adsorption process. The adsorption of lipase on a porous support with a hydrophobic surface enhances the stability of lipase after immobilization. The combination of hydrophobic and porous supports is used in many industrial applications due to the low economic value and easy realization on a large scale. Porous carriers have many advantages compared with nonporous carriers. Many studies have shown that porous supports have a better surface area and are able to carry more enzymes with higher immobilization rates. Lipase is also significantly stable in porous supports due to the indirect exposure to the harsh conditions of the reaction process. Thus, the adsorption of lipase on porous supports with hydrophobic properties improves the reusability, $\mathrm{pH}$ stability, thermostability, and operational and storage stability of lipase for long-term and large-scale applications.

\section{Patents}

There are no patents resulting from the work reported in this manuscript.

Author Contributions: N.F.M. and M.S.M.A. researched the literature and wrote the manuscript; R.N.Z.R.A.R., N.D.M.N., and F.M.S. discussed ideas and edited the manuscript. All authors have read and agreed to the published version of the manuscript.

Funding: This research received no external funding.

Conflicts of Interest: The authors declare no conflict of interest. The funding sponsors had no role in the design of the study; in the collection, analysis, or interpretation of data; in the writing of the manuscript; or in the decision to publish the results.

\section{References}

1. Sheldon, R.A.; van Pelt, S. Enzyme Immobilisation in Biocatalysis: Why, What and How. Chem. Soc. Rev. 2013, 42, 6223-6235. [CrossRef] [PubMed]

2. Zhang, D.D.; Yuwen, L.L.L.; Peng, L.L.L. Parameters Affecting the Performance of Immobilized Enzyme. J. Chem. Hindawi Publ. Corp. 2013. [CrossRef]

3. Yang, T.; Zheng, Y.D. State and Trends of Oil Crops Production in China; State and Trends of Oil Crops Production in China. OCL 2016, 23.

4. Villeneuve, P.; Muderhwa, J.M.; Graille, J.; Haas, M.J. Customizing lipases for biocatalysis:a survey of chemical, physical and molecular biological approaches. J. Mol. Catal. B Enzym. 2000, 9, 113-148. [CrossRef]

5. Guo, Z.; Bai, S.; Sun, Y. Preparation and characterization of immobilized lipase on magnetic hydrophobic microspheres. Enzyme Microb. Technol. 2003, 32, 776-782. [CrossRef]

6. Adlercreutz, P. Immobilisation and application of lipases in organic media. Chem. Soc. Rev. 2013, 42, 6406. [CrossRef] [PubMed]

7. Flood, M.T.; Keller, M.K. Safety Evaluation of Lipase Produced from Rhizopus oryzae: Summary of Toxicological Data. Regul. Toxicol. Pharmacol. 2003, 37, 293-304. [CrossRef]

8. Tecelão, C.; Guillén, M.; Valero, F.; Ferreira-Dias, S. Immobilized Heterologous Rhizopus oryzae Lipase: A Feasible Biocatalyst for the Production of Human Milk Fat Substitutes. Biochem. Eng. J. 2012, 67, $104-110$. [CrossRef]

9. Katchalski-Katzir, E.; Kraemer, D.M. Eupergit@C, a Carrier for Immobilization of Enzymes of Industrial Potential. J. Mol. Catal. B Enzym. 2000, 10, 157-176. [CrossRef]

10. Talekar, S.; Chavare, S. Optimization of Immobilization of $\alpha$-Amylase in Alginate Gel and Its Comparative Biochemical Studies with Free $\alpha$-Amylase. Recent Res. Sci. Technol. 2012, 4, 1-5.

11. Dwevedi, A. Enzyme Immobilization: Advances in Industry, Agriculture, Medicine, and the Environment; Springer: Berlin/Heidelberg, Germany, 2016; pp. 1-132.

12. Iqbal, J.; Afaq, S. Immobilization and stabilization of papain on chelating sepharose: A metal chelate regenerable carrier. Electron. J. Biotechnol. 2001, 4, 1-2. [CrossRef] 
13. Rehman, S.; Bhatti, H.N.; Bilal, M.; Asgher, M. Cross-Linked Enzyme Aggregates (CLEAs) of Pencilluim Notatum Lipase Enzyme with Improved Activity, Stability and Reusability Characteristics. Int. J. Biol. Macromol. 2016, 91, 1161-1169. [CrossRef] [PubMed]

14. Jesionowski, T.; Zdarta, J.; Krajewska, B.; Jakub, Z.; Krajewska, B. Enzyme immobilization by adsorption: A review. Adsorption 2014, 20, 801-821. [CrossRef]

15. Shuai, W.; Das, R.K.; Naghdi, M.; Brar, S.K.; Verma, M. A review on the important aspects of lipase immobilization on nanomaterials. Appl. Biochem. Biotechnol. 2017, 64, 496-508. [CrossRef] [PubMed]

16. Thangaraj, B.; Solomon, P.R. Immobilization of Lipases-A Review. Part I: Enzyme Immobilization. Chem. Biol. Eng. Rev. 2019, 6, 157-166. [CrossRef]

17. Thangaraj, B.; Solomon, P.R. Immobilization of Lipases-A Review. Part II: Carrier Materials. Chem. Biol. Eng. Rev. 2019, 6, 167-194. [CrossRef]

18. Fernandez-Lafuente, R.; Armisén, P.; Sabuquillo, P.; Fernández-Lorente, G.; Guisán, J.M. Immobilization of lipases by selective adsorption on hydrophobic supports. Chem. Phys. Lipids 1998, 93, 185-197. [CrossRef]

19. Filho, D.G.; Silva, A.G.; Guidini, C.Z. Lipases: Sources, immobilization methods, and industrial applications. Appl. Microbiol. Biotechnol. 2019, 103, 7399-7423. [CrossRef] [PubMed]

20. Rodrigues, R.C.; Virgen-Ortíz, J.J.; Santos, J.C.D.; Berenguer-Murcia, Á.; Alcantara, A.R.; Barbosa, O.; Fernandez-Lafuente, R. Immobilization of lipases on hydrophobic supports: Immobilization mechanism, advantages, problems, and solutions. Biotechnol. Adv. 2019, 37, 746-770. [CrossRef] [PubMed]

21. Jegannathan, K.R.; Abang, S.; Poncelet, D.; Chan, E.S.; Ravindra, P. Production of Biodiesel Using Immobilized Lipase-A Critical Review. Crit. Rev. Biotechnol. 2008, 28, 253-264. [CrossRef] [PubMed]

22. Karra-Châabouni, M.; Bouaziz, I.; Boufi, S.; Botelho do Rego, A.M.; Gargouri, Y. Physical immobilization of Rhizopus oryzae lipase onto cellulose substrate: Activity and stability studies. Colloids Surf. B 2008, 66, 168-177. [CrossRef] [PubMed]

23. Xu, L.; Ke, C.; Huang, Y.; Yan, Y. Immobilized Aspergillus niger Lipase with SiO2 Nanoparticles in Sol-Gel Materials. Catalysts 2016, 6, 149. [CrossRef]

24. Ali, Z.; Tian, L.; Zhang, B.; Ali, N.; Khan, M.; Zhang, Q. Synthesis of fibrous and non-fibrous mesoporous silica magnetic yolk-shell microspheres as recyclable supports for immobilization of Candida rugosa lipase. Enzyme Microb. Technol. 2017, 103, 42-52. [CrossRef] [PubMed]

25. Basri, M.; Yunus, W.M.Z.W.; Yoong, W.S.; Ampon, K.; Razak, C.N.A.; Salleh, A.B. Immobilization of Lipase from Candida rugosa on Synthetic Polymer Beads for Use in the Synthesis of Fatty Esters. J. Chem. Technol. Biotechnol. 1996, 66, 169-173. [CrossRef]

26. Cesarini, S.; Pastor, F.I.J.; Diaz, P. Improvement of P.aeruginosa 42A2 lipase preparations for FAMEs production, both in immobilized and soluble form. J. Mol. Catal. B Enzym. 2014, 99, 1-7.

27. Nawani, N.; Singh, R.; Kaur, J. Immobilization and stability studies of a lipase from thermophilic Bacillus sp: The effect of process parameters on immobilization of enzyme. Electron. J. Biotechnol. 2006, 9, 559-565.

28. Yang, D.; Rhee, J.S. Continuous hydrolysis of olive oil by immobilized lipase in organic solvent. Biotechnol. Bioeng. 1992, 40, 748-752. [CrossRef] [PubMed]

29. Li, C.; Zhang, G.; Liu, N.; Liu, L. Preparation and Properties of Rhizopus oryzae Lipase Immobilized Using an Adsorption-Crosslinking Method. Int. J. Food Prop. 2016, 19, 1776-1785. [CrossRef]

30. Biasutti, M.A.; Abuin, E.B.; Silber, J.J.; Correa, N.M.; Lissi, E.A. Kinetics of Reactions Catalyzed by Enzymes in Solutions of Surfactants. Adv. Colloid Interface Sci. 2008, 136, 1-24. [CrossRef] [PubMed]

31. Mihailoviф, M.; Stojanoviф, M.; Banjanac, K.; Careviф, M.; Prlainovi $\not$, N.; Milosaviф, N.; Bezbradica, D. Immobilization of lipase on epoxy-activated Purolite ${ }^{\circledR}$ A109 $\mathrm{e}^{\circledR}$ its post-immobilization stabilization. Process Biochem. 2014, 49, 637-646. [CrossRef]

32. Kharrat, N.; Ali, Y.B.; Marzouk, S.; Gargouri, Y.-T.; Karra-Châabouni, M. Immobilization of Rhizopus oryzae Lipase on Silica Aerogels by Adsorption: Comparison with the Free Enzyme. Process Biochem. 2011, 46, 1083-1089. [CrossRef]

33. DiCosimo, R.; McAuliffe, J.; Poulose, A.J.; Bohlmann, G.; Kumar, H.; Satyanarayanan, T.; Langan, P. Industrial use of immobilized enzymes. Chem. Soc. Rev. 2013, 42, 6437-6474. [CrossRef] [PubMed]

34. Kumar, A.; Dhar, K.; Kanwar, S.S.; Arora, P.K. Lipase catalysis in organic solvents: Advantages and applications. Biol. Proced. Online 2016, 18, 2. [CrossRef] [PubMed] 
35. Chang, S.W.; Shaw, J.F.; Yang, K.H.; Chang, S.F.; Shieh, C.J. Studies of optimum conditions for covalent immobilization of Candida rugosa lipase on poly( $\gamma$-glutamic acid) by RSM. Bioresour. Technol. 2008, 99, 2800-2805. [CrossRef] [PubMed]

36. Bayne, L.; Ulijn, R.V.; Halling, P.J. Effect of pore size on the performance of immobilized enzymes. Chem. Soc. Rev. 2013, 42, 9000-9010. [CrossRef] [PubMed]

37. Li, Y.; Wu, J.-Q.; Long, N.-B.; Zhang, R.-F. Efficient immobilization of phospholipase D on novel polymer supports with hierarchical pore structures. Int. J. Biol. Macromol. 2019, 141, 60-67. [CrossRef] [PubMed]

38. Taubert, M.; Beckmann, J.; Lange, A.; Enke, D.; Klepel, O. Attempts to design porous carbon monoliths using porous concrete as a template. Microporous Mesoporous Mater. 2014, 197, 58-62. [CrossRef]

39. Samui, S.K.; Sahu, S.K. One-pot synthesis of microporous nanoscale metal organic frameworks conjugated with laccase as a promising biocatalyst. New J. Chem. 2018, 42, 4192-4200. [CrossRef]

40. Gao, S.; Wang, Y.; Wang, T.; Luo, G.; Dai, Y. Immobilization of lipase on methyl-modified silica aerogels by physical adsorption. Bioresour. Technol. 2009, 100, 996-999. [CrossRef] [PubMed]

41. Mohamad, N.; Marzuki, N.; Buang, N.; Huyop, F.; Wahab, R. An overview of technologies for immobilization of enzymes and surface analysis techniques for immobilized enzymes. Biotechnol. Biotechnol. Equip. 2015, 29, 205-220. [CrossRef] [PubMed]

42. Hu, Z.F.; Xu, L.Q.; Wen, X.H. Mesoporous silicas synthesis and application for lignin peroxidase immobilization by covalent binding method. J. Environ. Sci.-China 2013, 25, 181-187. [CrossRef]

43. Ramachandran, P.; Narayanan, G.K.; Gandhi, S.; Sethuraman, S.; Krishnan, U.M. Rhizopus oryzae lipase immobilized on hierarchical mesoporous silica supports for transesterification of rice bran oil. Appl. Biochem. Biotechnol. 2015, 175, 2332-2346. [CrossRef] [PubMed]

44. Pegah, S.; Nabavi, Z.; Björn, ̊.. Immobilization of enzymes in mesoporous silica particles: Protein concentration and rotationalmobility in the pores. J. Phys. Chem. B 2017, 121, 2575-2583.

45. Lee, C.H.; Lin, T.S.; Mou, C.Y. Mesoporous materials for encapsulating enzymes. NanoToday 2009, 4, $165-179$. [CrossRef]

46. Carlsson, N.; Gustafsson, H.; Thörn, C.; Olsson, L.; Holmberg, K.; Åkerman, B. Enzymes immobilized in mesoporous silica: A physical-chemical perspective. Adv. Colloid Interface Sci. 2014, 205, 339-360. [CrossRef] [PubMed]

47. Wen, L.Y.; Gao, A.C.; Cao, Y.; Frantisek, S.; Tan, T.W.; Lv, Y.Q. Layer-by-layer assembly of metal-organic frameworks in macroporous polymer monolith and their use for enzyme immobilization. Macromol. Rapid Commun. 2016, 37, 551-557. [CrossRef] [PubMed]

48. Pavel, I.A.; Prazeres, S.F.; Montalvo, G.; Ruiz, C.G.; Nicolas, V.; Celzard, A.; Dehez, F.; Canabady-Rochelle, L.; Canilho, N.; Pasc, A. Effect of meso vs macro size of hierarchical porous silica on the adsorption and activity of immobilized $\beta$-galactosidase. Langmuir 2017, 33, 3333-3340. [CrossRef] [PubMed]

49. Morhardt, C.; Ketterer, B.; Heißler, S.; Franzreb, M. Direct quantification of immobilized enzymes by means of FTIR ATR spectroscopy-A process analytics tool for biotransformations applying non-porous magnetic enzyme carriers. J. Mol. Catal. B Enzym. 2014, 107, 55-63. [CrossRef]

50. Valivety, R.H.; Halling, P.J.; Peilow, A.D.; Macrae, A.R. Relationship between water activity and catalytic activity of lipases in organic media: Effects of supports, loading and enzyme preparation. Eur. J. Biochem. 1994, 222, 461-466. [CrossRef] [PubMed]

51. Pencreac'h, G.; Leullier, M.; Baratti, J.C. Properties of Free and Immobilized Lipase from Pseudomonas cepacia. Biotechnol. Bioeng. 1997, 56, 181-189. [CrossRef]

52. Naya, M.; Imai, M. Impact of physicochemical character of hydrophobic porous carrier on reactivity of immobilized lipase progressing toward higher reaction rate and high yield in repeated use. Procedia Eng. 2012, 42, 1004-1015. [CrossRef]

53. Al-Duri, B.; Yong, Y.P. Characterisation of the equilibrium behaviour of lipase PS (from Pseudomonas) and lipolase 100 L (from Humicola) onto Accurel EP100. J. Mol. Catal. B Enzym. 1997, 3, 177-188. [CrossRef]

54. Salis, A.; Sanjust, E.; Solinas, V.; Monduzzi, M. Characterisation of Accurel MP1004 polypropylene powder and its use as a support for lipase immobilization. J. Mol. Catal. B Enzym. 2003, 24, 75-82. [CrossRef]

55. Manoel, E.A.; Ribeiro, M.F.P.; dos Santos, J.C.S.; Coelho, M.A.Z.; Simas, A.B.C.; Fernandez-Lafuente, R.; Freire, D.M.G. Accurel MP 1000 as a support for the immobilization of lipase from Burkholderia cepacia: Application to the kinetic resolution of myo -inositol derivatives. Process Biochem. 2015, 50, 1557-1564. [CrossRef] 
56. Foresti, M.L.; Ferreira, M.L. Ethanol pretreatment effect and particle diameter issues on the adsorption of Candida rugosa lipase onto polypropylene powder. Appl. Surf. Sci. 2004, 238, 86-90. [CrossRef]

57. Cesarina, S.; Infanzon, B.; Pastor, F.I.J.; Diaz, P. Fast and economic immobilization methods described for non-commercial Pseudomonas lipases. BMC Biotechnol. 2014, 14, 1472-6750. [CrossRef] [PubMed]

58. Silveira, E.A.; Moreno-Perez, S.; Basso, A.; Serban, S.; Pestana-Mamede, R.; Tardioli, P.W.; Sanchez-Farinas, C.; Castejon, N.; Fernandez-Lorente, G.; Rocha-Martin, J.; et al. Biocatalyst engineering of Thermomyces lanuginosus lipase adsorbed on hydrophobic supports: Modulation of enzyme properties for ethanolysis of oil in solvent-free systems. J. Biotechnol. 2019, 289, 126-134. [CrossRef] [PubMed]

59. Séverac, E.; Galy, O.; Turon, F.; Pantel, C.A.; Condoret, J.S.; Monsan, P.; Marty, A. Selection of CalB immobilization method to be used in continuous oil transesterification: Analysis of the economical impact. Enzym. Microb. Technol. 2011, 48, 61-70. [CrossRef] [PubMed]

60. Poppe, J.K.; Garcia-Galan, C.; Matte, C.R.; Fernandez-Lafuente, R.; Rodrigues, R.C.; Ayub, M.A.Z. Optimization of synthesis of fatty acid methyl esters catalyzed by lipase B from Candida antarctica immobilized in hydrophobic supports. J. Mol. Catal. B Enzym. 2013, 94, 51-56. [CrossRef]

61. Chen, B.; Miller, E.M.; Miller, L.; Maikner, J.J.; Gross, R.A. Effects of Macroporous Resin Size on Candida antarctica Lipase B Adsorption, Fraction of Active Molecules, and Catalytic Activity for Polyester Synthesis. Langmuir 2007, 23, 1381-1387. [CrossRef] [PubMed]

62. Chen, B.; Miller, M.E.; Gross, R.A. Effects of Porous Polystyrene Resin Parameters on Candida antarctica Lipase B Adsorption, Distribution, and Polyester Synthesis Activity. Langmuir 2007, 23, 6467-6474. [CrossRef] [PubMed]

63. Sankar, K.; Achary, A. Bio-ceramic, mesoporous cuttlebone of Sepia officinalis is an ideal support for the immobilization of Bacillus subtilis AKL13 lipase: Optimization, adsorption, thermodynamic and reaction kinetic studies. Chem. Papers 2019, 74, 459-470. [CrossRef]

64. Anand, A.; Weatherley, L.R. The performance of microbial lipase immobilized onto polyolefin supports for hydrolysis of high oleate sunflower oil. Process Biochem. 2018, 68, 100-107. [CrossRef]

65. Bassi, J.J.; Todero, L.M.; Lage, F.A.P.; Khedy, G.I.; Ducas, J.D.; Custódio, A.P.; Pinto, M.A.; Mendes, A.A. Interfacial activation of lipases on hydrophobic support and application in the synthesis of a lubricant ester. Int. J. Biol. Macromol. 2016, 92, 900-909. [CrossRef] [PubMed]

66. Gustafsson, H.; Johansson, E.M.; Barrabino, A.; Odén, M.; Holmberg, K. Immobilization of lipase from Mucor miehei and Rhizopus oryzae into mesoporoussilica-The effect of varied particle size and morphology. Colloids Surf. B Biointerfaces 2012, 100, 22-30. [CrossRef] [PubMed]

67. Kalantari, M.; Yu, M.; Yang, Y.; Strounina, E.; Gu, Z.; Huang, X.; Zhang, J.; Song, H.; Yu, C. Tailoring mesoporous-silica nanoparticles for robust immobilization of lipase and biocatalysis. Nano Res. 2017, 10, 605-617. [CrossRef]

68. Lage, F.A.P.; Bassi, J.J.; Corradini, M.C.C.; Todero, L.M.; Luiz, J.H.H.; Mendes, A.A. Preparation of a biocatalyst via physical adsorption of lipase from Thermomyces lanuginosus on hydrophobic support to catalyze biolubricant synthesis by esterification reaction in a solvent-free system. Enzym. Microb. Technol. 2016, 84, 56-67. [CrossRef] [PubMed]

69. Liu, T.; Liu, Y.; Wang, X.; Li, Q.; Wang, J.; Yan, Y. Improving catalytic performance of Burkholderia cepacia lipase immobilized on macroporous resin NKA. J. Mol. Catal. B Enzym. 2011, 71, 45-50. [CrossRef]

70. Meng, X.; Xu, G.; Zhou, Q.L.; Wu, J.P.; Yang, L.R. Improvements of lipase performance in high-viscosity system by immobilization onto a novel kind of poly (me thylmethacrylate-co-divinylbenzene) encapsulated porous magnetic microspherecarrier. J. Mol. Catal. B Enzym. 2013, 89, 86-92. [CrossRef]

71. Quirós, M.; García, A.B.; Montes-Morán, M.A. Influence of the support surface properties on the protein loading and activity of lipase/mesoporous carbon biocatalysts. Carbon N. Y. 2011, 49, 406-415. [CrossRef]

72. Rios, N.S.; Pinheiro, M.P.; Lima, M.L.B.; Freire, D.M.G.; da Silva, I.J.; Rodríguez-Castellón, E.; de Sant'Ana, H.B.; Macedo, A.C.; Gonçalves, L.R.B. Pore-expanded SBA-15 for the immobilization of a recombinant Candida antarctica lipase B: Application in esterification and hydrolysis as model reactions. Chem. Eng. Res. Des. 2018, 129, 12-24. [CrossRef]

73. Wang, B.; Li, W.; Wu, B.; He, B. Efficient resolution of 3-phenoxy-1, 2-propanediol by immobilized lipase on amphiphilic comb polymer modified TiO2. J. Mol. Catal. B Enzym. 2014, 106, 105-110. [CrossRef] 
74. Zheng, M.; Xiang, X.; Wang, S.; Shi, J.; Deng, Q.; Huang, F.; Cong, R. Lipase immobilized in ordered mesoporous silica: A powerful biocatalyst for ultrafast kinetic resolution of racemic secondary alcohols. Process Biochem. 2017, 53, 102-108. [CrossRef]

75. Dong, Z.; Jiang, M.-Y.; Shi, J.; Zheng, M.-M.; Huang, F.-H. Preparation of Immobilized Lipase Based on Hollow Mesoporous Silica Spheres and Its Application in Ester Synthesis. Molecules 2019, 24, 395. [CrossRef] [PubMed]

76. Malcata, F.X.; Reyes, H.R.; Garcia, H.S.; Hill, C.G.; Amundson, C.H. Immobilized Lipase Reactors for Modification of Fats and Oils-A Review. J. Am. Oil Chem. Soc. 1990, 67, 890-910. [CrossRef]

77. Jun, L.Y.; Yon, L.S.; Mubarak, N.; Bing, C.H.; Pan, S.; Danquah, M.K.; Khalid, M. An overview of immobilized enzyme technologies for dye and phenolic removal from wastewater. J. Environ. Chem. Eng. 2019, 7, 102961. [CrossRef]

78. Gotor-Fernández, V.; Busto, E.; Gotor, V. Candida antarctica lipase B: An ideal biocatalyst for the preparation of nitrogenated organic compounds. Adv. Synth. Catal. 2006, 348, 797-812. [CrossRef]

79. Zhao, K.; Di, Q.; Cao, X.; Wang, M.; Deng, L.; Wang, F. Production of Biodiesel Using Immobilized Lipase and the Characterization of Different Co-Immobilizing Agents and Immobilization Methods. Sustainability 2016, 8, 764. [CrossRef]

80. Brígida, A.I.S.; Pinheiro, A.D.T.; Ferreira, A.L.O.; Gonçalves, L.R.B. Immobilization of Candida antarctica lipase B byadsorption to green coconut fiber. Appl. Biochem. Biotechnol. 2008, 146, 173-187. [CrossRef] [PubMed]

81. Liu, D.M.; Chen, J.; Shi, Y.P. Advances on methods and easy separated support materials for enzymes immobilization. Trends Anal. Chem. 2018, 102, 332-342. [CrossRef]

82. Tacias-Pascacio, V.G.; Peirce, S.; Torrestiana-Sanchez, B.; Yates, M.; Rosales-Quintero, A.; Virgen-Ortíz, J.J.; Fernandez-Lafuente, R. Evaluation of different commercial hydrophobic supports for the immobilization of lipases: Tuning their stability, activity and specificity. RSC Adv. 2016, 6, 100281-100294. [CrossRef]

83. Fernandez-Lorente, G.; Rocha-Martín, J.; Guisan, J.M. Immobilization of Lipases by Adsorption on Hydrophobic Supports: Modulation of Enzyme Properties in Biotransformations in Anhydrous Media. Methods Mol. Biol. 2020, 143-158.

84. Bosley, J.A.; Peilow, A.D. Immobilization of lipases on porous polypropylene: Reduction in esterification efficiency at low loading. J. Am. Oil Chem. Soc. 1997, 74, 107-111. [CrossRef]

85. Gitlesen, T.; Bauer, M.; Adlercreutz, P. Adsorption of lipase on polypropylene powder. Biochim. Biophys. Acta 1997, 1345, 188-196. [CrossRef]

86. Al-Duri, B.; Yong, Y.P. Lipase immobilization: An equilibrium study of lipases immobilized on hydrophobic and hydrophilic/hydrophobic supports. Biochem. Eng. J. 2000, 4, 207-215. [CrossRef]

87. Lin, H.-Y.; Tsai, S.-W. Dynamic kinetic resolution of (RS)-naproxen 2, 2, 2-trifluoroethyl ester via lipase-catalyzed hydrolysis in micro-aqueous isooctane. J. Mol. Catal. B Enzym. 2003, 24-25, 111-120. [CrossRef]

88. Peirce, S.; Tacias-Pascacio, V.; Russo, M.; Marzocchella, A.; Virgen-Ortíz, J.; Fernandez-Lafuente, R. Stabilization of Candida antarctica Lipase B (CALB) Immobilized on Octyl Agarose by Treatment with Polyethyleneimine (PEI). Molecules 2016, 21, 751. [CrossRef] [PubMed]

89. Mateo, C.; Palomo, J.M.; Fernandez-Lorente, G.; Guisan, J.M.; Fernandez-Lafuente, R. Improvement of enzyme activity, stability and selectivity via immobilization techniques. Enzym. Microb. Technol. 2007, 40, 1451-1463. [CrossRef]

90. Xue, P.; Hu, C.-M.; Yan, X.-H.; Fang, G.-L.; Shen, H.-F. Enhancement of activity and reusability of lipase immobilized on magnetic mesoporous silica for the resolution of racemic secondary alcohols. J. Chin. Chem. Soc. 2018, 66, 427-433. [CrossRef]

91. Ghamgui, H.; Miled, N.; Karra-chaâbouni, M.; Gargouri, Y. Immobilization Studies and Biochemical Properties

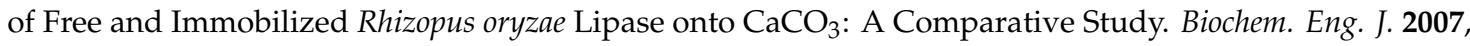
37, 34-41. [CrossRef]

92. Hirata, D.B.; Albuquerque, T.L.; Rueda, N.; Sánchez-Montero, J.M.; Garcia-Verdugo, E.; Porcar, R.; Fernandez-Lafuente, R. Advantages of Heterofunctional Octyl Supports: Production of 1, 2-Dibutyrin by Specific and Selective Hydrolysis of Tributyrin Catalyzed by Immobilized Lipases. ChemistrySelect 2016, 1, 3259-3270. [CrossRef] 
93. Brady, D.; Jordaan, J. Advances in enzyme immobilization. Biotechnol. Lett. 2009, 31, 1639-1650. [CrossRef] [PubMed]

94. Gerday, C.; Aittaleb, M.; Bentahir, M.; Chessa, J.-P.; Claverie, P.; Collins, T.; Feller, G. Cold-adapted enzymes: From fundamentals to biotechnology. Trends Biotechnol. 2000, 18, 103-107. [CrossRef]

95. Pereira, S.E.; Fernandes, K.F.; Ulhoa, C.J. Immobilization of Cryptococcus flavus $\alpha$-amylase on glass tubes and its application in starch hydrolysis. Starch-Stärke 2016, 69, 1600189. [CrossRef]

96. Cavalcanti, E.D.C.; Aguieiras, É.C.G.; da Silva, P.R.; Duarte, J.G.; Cipolatti, E.P.; Fernandez-Lafuente, R.; da Silva, J.A.C.; Freire, D.M.G. Improved production of biolubricants from soybean oil and different polyols via esterification reaction catalyzed by immobilized lipase from Candida rugosa. Fuel 2018, 215, 705-713. [CrossRef]

97. de Abreu, L.; Fernandez-Lafuente, R.; Rodrigues, R.C.; Volpato, G.; Ayub, M.A.Z. Efficient purification-immobilization of an organic solvent-tolerant lipase from Staphylococcus warneri EX17 on porous styrene-divinylbenzene beads. J. Mol. Catal. B Enzym. 2014, 99, 51-55. [CrossRef]

98. Gao, Z.; Chu, J.; Jiang, T.; Xu, T.; Wu, B.; He, B. Lipase immobilization on functionalized mesoporous TiO2: Specific adsorption, hyperactivation and application in cinnamyl acetate synthesis. Process Biochem. 2018, 64, 152-159. [CrossRef]

99. Liu, N.; Wang, Y.; Zhao, Q.; Cui, C.; Fu, M.; Zhao, M. Immobilisation of Lecitase ${ }^{\circledR}$ Ultra for production of diacylglycerols by glycerolysis of soybean oil. Food Chem. 2012, 134, 301-307. [CrossRef]

100. Guerrand, D. Lipases industrial applications: Focus on food and agroindustries. OCL 2017, 24. [CrossRef]

101. Choudhury, P. Industrial application of lipase: A review. Biopharm. J. 2015, 11, 41-47.

102. Gao, Y.; Tan, T.; Nie, K.; Wang, F. Immobilization of Lipase on Macroporous Resin and Its Application in Synthesis of Biodiesel in Low Aqueous Media. Chin. J. Biotechnol. 2006, 22, 114-118. [CrossRef]

103. Sun, J.; Chen, Y.; Sheng, J.; Sun, M. Immobilization of Yarrowia lipolytica Lipase on Macroporous Resin Using Different Methods: Characterization of the Biocatalysts in Hydrolysis Reaction. BioMed Res. Int. 2015.

104. Cai, X.; Zhang, M.; Wei, W.; Zhang, Y.; Wang, Z.; Zheng, J. The Immobilization of Candida antarctica lipase B by ZIF-8 encapsulation and macroporous resin adsorption: Preparation and characterizations. Biotechnol. Lett. 2019, 42, 269-276. [CrossRef] [PubMed]

105. Hernandez, K.; Fernandez-Lafuente, R. Lipase B from Candida antarctica immobilized on octadecyl sepabeads: A very stable biocatalyst in the presence of hydrogen peroxide. Process Biochem. 2011, 46, 873-878. [CrossRef]

106. Martins, A.B.; Friedrich, J.L.R.; Cavalheiro, J.C.; Garcia-Galan, C.; Barbosa, O.; Ayub, M.A.Z.; Fernandez-Lafuente, R.; Rodrigues, R.C. Improved production of butyl butyrate with lipase from Thermomyces lanuginosus immobilized on styrene-divinylbenzene beads. Bioresour. Technol. 2013, 134, 417-422. [CrossRef] [PubMed]

107. Zhao, X.; Fan, M.; Zeng, J.; Du, W.; Liu, C.; Liu, D. Kinetics of lipase recovery from the aqueous phase of biodiesel production by macroporous resin adsorption and reuse of the adsorbed lipase for biodiesel preparation. Enzym. Microb. Technol. 2013, 52, 226-233. [CrossRef] [PubMed]

(C) 2020 by the authors. Licensee MDPI, Basel, Switzerland. This article is an open access article distributed under the terms and conditions of the Creative Commons Attribution (CC BY) license (http://creativecommons.org/licenses/by/4.0/). 